\section{ETHER CLONUS.}

\section{To the Elitor of THE LANCET.}

SIR,-In the issue of THE LANCET of April 13th Dr. Henri Vignes gives some information on the condition known as "ether clonus" or "ether rigor." My own observations have been somewhat similar to those of Dr. Vignes. I have seen clonus occur with ether given by the open, semi-open, or closed methods, and also in C.E. $(1: 2)$, but never any clonus or rigors during the administration of pure chloroform. The greatest frequency occurs with ether given by the open and semi-open methods, and least of all in C.E. administrations.

The condition, as far as my own experience is concerned, is confined to men. I have never had or seen a case in a woman or child. I have also noticed that it is much more common in military patients than in men employed in civil life in any capacity. It may be possible, as $\mathrm{Dr}$ W. D. Anderson suggests in ThE LANCET of Dec. 22nd, 1917 , p. 949 , that this is a consequence of the nervous state due to modern war conditions. In civil practice the condition appears to be confined to the limbs, as I have never seen it present in operations on the head chest, or abdomen. This fact might explain why ether clonus appears more common in soldiers, because a considerable amonnt of military surgery is composed of work on the extremities. It is quite common to see a rigor or clonus started when a patient, who is anæsthetised, is moved on the table for some reason or other, although before he was perfectly quiet.

The pathology of this troublesome condition is wrapped in mystery. No theory appears to be entirely satisfactory. was always taught that the patient was not fully anæsthetised, but I am convinced that this is wrong, because my own patients presented all the signs of a normal anæsthesia except for the clonus. My own theory is that it is due either to asphyxia, set up by lack of air and the narrowing of the air-passage by congestion due to the ether vapour, or a condition something akin to the clonic movements seen in the administration of nitrous oxide alone. This theory may appear on the face of it ridiculous, when thinking of the administration of ether by the open method, but I must say that I have seen patients "soaked" to asphyxia by this method, because when the ganze gets sodden there is very little air passing through the meshes, whereas in closed ether the rule is to give air at regulated intervals.

I have never known the clonus persist all through the operation except in one case of gunshot wound of the right side of the head, when the left leg was in a state of clonus before, during, and after the operation. The treatment is very unsatisfactory, but unless the condition persists all through the operation, it is often relieved by increasing the amount of air, or by changing from ether to pure chloroform if the case permits. - $\mathrm{I}$ am, Sir, yours faithfully,

$$
\text { J. B. H. HoLROYD, }
$$

Lieut., R.A.M.C. ; Anæsthetist, Queen Mary's Military Hos-

\section{THE PARLIAMENTARY REPRESENTATION OF THE COMBINED UNIVERSITIES.}

\section{To the Editor of THE LANOET.}

SIR,--In your issue of April 20th Dr. E. Rowland Fothergill takes exception to the formation of a political association in connexion with the combined English Universities, though at the same time he somewhat incon sistently snggests that those who think like him should take action to support a candidate who would hold views similar to him. We would point out that party politics consist fundamentally of the coopperation for political purposes of those who hold the same political views, and those who hold Conservative and Unionist views have as much right to coöperate in a University constituency as a group of people who hold any other opinions in common.

His letter is inaccurate in certain particulars, and we would point out that he was informed some weeks ago, in reply to a post-card from him, exactly how our committee came to be appointed. It is not self-constituted, but was elected at a meeting to which we invited all the graduates resident in London of the seven Universities whose names and addresses could be found. It is true that the attendance at the meeting was small, but everything must have a beginning. In addition, however, to those who had accepted the invitation, a very much larger number had written expressing approval of the proposal to form an association.
Dr. Fothergill suggests that we are endeavouring to secure the election of a candidate who holds our views; this, of course, is the main object of our association, just as it would be the main object of the association which he suggest: should be formed, but as there are to be two members to the division and not one, and as the election will be in accordance with the principle of proportional representation, it is obvious that our association, however successful it might be, could not hope to monopolise the representation of the division. Dr. Fothergill indulges in the gratuitous assump tion that our candidate will not be keen on social questions. He may be assured that the undersigned, at any rate, will not support a candidate who is not desirous of improving the condition of the masses of the people in this country, though, at the same time, we would point out to him that many of the proposals which are described as "social reforms" merely aggravate the disease which they profess to cure. In any event, we think it a sine qua non that the members for the division should be giraduates of one or more of the seven Universities concerned, as only in that way can suitable representation be secured. He suggests that the University authorities should wake up in the matter in view of our activities, and, while we appreciate the implied com. pliment, we would point out, if by the University authorities he means the respective Senates, that it would be wholly improper for these official bodies to take any collective action, even if the bulk of the members thereof were electors in the division, but when, as a matter of fact, the majority of the members of these bodies are graduates of other Universities-e.g., Oxford, "Cambridge, London, and Edinburgh-and therefore not electors in the division, it is even more obvious that they should not take any part in the matter.

In conclusion, we would state that our association, in addition to its purely political objects, also intends to interest itself in the advancement of education and the extension of human knowledge, and the best justification for our action is the fact that already communications expressing approval have been received from graduates who are in number more than twice as many as the aggregate membership of the Senates of the seven Universities.

$$
\text { We are, Sir, yours faithfully, }
$$

W. M. Aввот ANDERSON, Chairman,

Herbert G. Williams, Hon. See.,

April 23rd, 1918 Combined Universities Conservative and Unionist Association.

\section{ARTIFICIAL FROST-BITE}

\section{Zo the Editor of THE LANCET.}

SIR, - Your correspondent, Mr. Leighton. Kesteven, would appear to suggest that the effect produced by ethyl chloride is rather one of "chilling" of the tissues than of actual "frost-bite," despite the fact that this substance carries the tissues down to below $-6^{\circ} \mathrm{C}$. which $\mathrm{I}$ maintain to be a critical temperature. This conclusion he bases on the fact that although considerable swelling is produced by the exudation there is nevertheless no direct necrosis of tissue.

I believe the explanation of this paradox to be as follows. The effect of ethyl chloride is a very superficial one, and as usually used the period of extreme exposure is but momentary ; under these circumstances it is only the outermost layers of the epidermis-i.e., the partially keratinised layers, which are actually at a temperature below $-6^{\circ} \mathrm{C}$. The deeper, live layers of the epidermis being at varying temperatures above this critical limit, no direct necrosis is to be expected, and the swelling which follows is due to the effect of " chilling" on the underlying tissues, being therefore strictly analogous to "trench foot." If the exposure to ethyl chloride be prolonged, however, the thin parchment-like plaque of solidified tissue, which first forms, will be found to increase in thickness until it includes the whole of the dermis; direct death of the cells of the Malpighian layer now occurs and necrosis follows, not of necessity leading to ulceration but to eventual desquamation, thinning of epithelium, and fine scarring.

Fxudation occurs both in "chilling" and true "frostbite," and any additional destruction due to this may be prevented by multiple incisions, \&c., as your correspondent suggests. I have tried this experimentally and found it to be efficient. The value of freezing as a local anæsthetic has probably been overestimated, and in view of the above considerations with regard to its after-effects it should be used with considerable reserve.-I am, Sir, yours faithfully,

Harley-street, W., April 17th, 1918. NORMAN C. LAKE. 